\title{
Water shortages in Beaufort West: Lessons learnt and applied during the 2009-2011 and 2017-2019 droughts
}

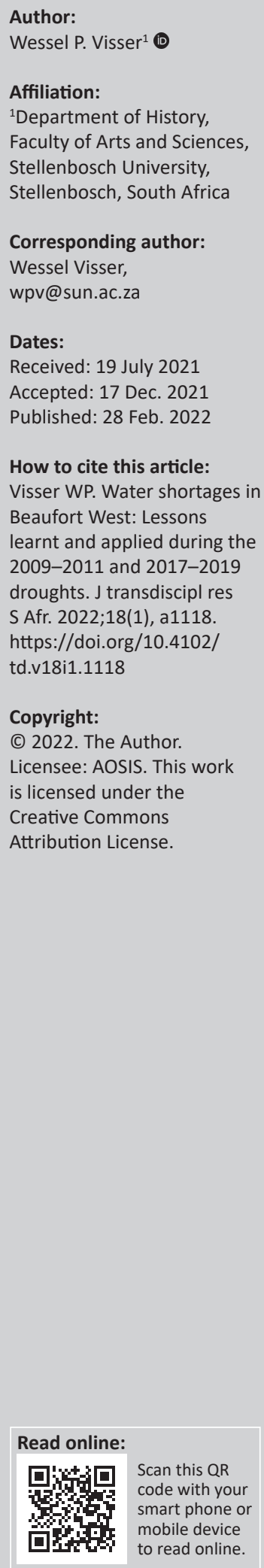

Increasing and prolonged droughts have become a feature of the South African environmental landscape. This article investigates the sustainability of water procurement to the town of Beaufort West and the reasons for the town's water provision crises during the droughts of 2009-2011 and 2017-2019. Emergency measures were implemented to alleviate the serious water shortages during these droughts. Data to illustrate population increases and precipitation decreases, which impacted on the town's water resources, were collected from census records of Statistics South Africa and the Department of Water and Sanitation, respectively. A number of risk factors contributed to the town's water crises, for example, unsustainable water extraction at times of serious droughts, poor water monitoring, metering and attention to leakages, an expansion of informal settlements within the municipal boundaries of Beaufort West, as well as annual rainfall patterns that became increasingly unpredictable. The article concludes that water resource development had not kept pace with demand; therefore water infrastructure should be built with enough capacity to cope with regular dry periods. Equilibrium should be reached between the water expectations of the community and the water availability to avoid future social instability in water-stressed towns such as Beaufort West. Rainfall data indicate that precipitation patterns in the arid regions of South Africa are decreasing; therefore the water shortage experience of Beaufort West during the recent droughts serves as a clear and present warning that rural towns in these regions should seek and implement alternative water augmentation strategies timeously.

Keywords: Beaufort West; drought; Gamka Dam; groundwater; water load shedding; reclamation plant; unsustainable water extraction.

\section{Introduction}

The historiography of water provision has a relatively long record in Southern Africa, and many of these histories also focussed on the quest for water during periods of severe drought. For example, Bodill referred to the augmentation of Port Elizabeth's (Gqeberha) vulnerable water supply from the Orange River in dry periods, ${ }^{1}$ Grant explained how periodic droughts and population growth in greater Cape Town ensured a continued search for new water sources during the 19th and 20th centuries, ${ }^{2}$ Visser et al. ${ }^{3}$ sketched the story of emergency water provision to Saldanha during the World War II and Musemwa discussed the hydro-politics of the Zimbabwean government prohibiting political dissidents in Bulawayo access to potable water during droughts. ${ }^{4}$

Increasing and prolonged drought conditions have prompted urgent research on the sustainability of water procurement and provision to rural communities in the arid interior of South Africa. As early as 2009, a study by Le Maitre et al. $^{5}$ focused on the challenge to provide adequate water resources in the water scarce region of the Little Karoo. The research area entailed the catchment of the Gouritz River system including the districts of Beaufort West in the north, Touwsrivier in the west, Uniondale in the east and Riversdale in the south. Holloway et al. ${ }^{6}$ published a report on the acute water shortages that occurred in towns in the Eden and Central Karoo District Municipalities during the 2009-2011 drought. Meissner and Jacobs-Mata ${ }^{7}$ probed the South African water sector's long-term national drought policy and strategy to improve the country's response to future droughts. Schreiner et al. ${ }^{8}$ investigated the economic impacts of drought and water shortages on agriculture, livestock, tourism, mining, and business during 2011-2016 whereas research by Tfwala et al. ${ }^{9}$ determined the occurrence and severity of droughts and interannual rainfall variability trends in the Ghaap plateau, Northern Cape Province. Zhang et al. $^{10}$ presented a conceptual framework within which numerical modelling of aquifer systems is operated to improve water security. Visser ${ }^{11}$ investigated the chronology of Cape Town's 20152018 drought and the various measures imposed by the city council to preserve dwindling water 
supplies to try and avert the so-called 'Day Zero' scenario when its water resources would be depleted.

The studies mentioned above are focused on the problems experienced by predominantly agricultural communities under the strain of serious droughts and efforts to provide water security in arid regions such as the Karoo, the Northern Cape, the West Coast and even Cape Town as a city with limited freshwater resources. However, there is a lacuna in the literature on water studies that focus on the responses and dynamics of rural town communities with a history of coping with water provision struggles during times of severe drought duress. This article investigates the reasons for the water provision crises of the town of Beaufort West in the Central Karoo region during the droughts of 2009-2011 and 2017-2019 and the innovative solutions reached to alleviate the problems of water scarcity.

\section{Research methodology and data analysis}

The study is based on comprehensive research into the history and processes of water provision to water-stressed rural towns in South Africa, with a specific focus on Beaufort West. Archival research was based on the following: Beaufort West municipal council minutes, reports and documents preserved in the Western Cape Archives and Records Service (WCARS) in Cape Town. This research material was complemented with data from various published scientific articles and reports, press releases and media reports pertaining to Beaufort West's water woes covering the period 2008-2020.

In addition, data were collected from the official census records, dating from 1921 to 2011 via Statistics South Africa. The study only made use of census records from years where a full population count was held. A graph was created to demonstrate growing population tendencies over time in Beaufort West that also put pressure on the town's available water sources during times of water duress. ${ }^{12}$

Annual precipitation data were gathered from the South African Weather Service (SAWS) for the period 1993-2020. These data were used to create two graphs, the first provided a representation of annual rainfall for the area by adding the total precipitation for each year and dividing the total of all the years from 1993 to 2020 by the number of years (i.e. 27 years). The second graph is known as a Standard Precipitation Index (SPI). The SAWS data were processed and analysed using the SPI software package of the University of Nebraska's Drought Mitigation Centre. This was performed to calculate the average rainfall in comparison to the previous 12 months for each year over a 40 -year period. The advantage of using an SPI over a 12-month period is that it highlights how the rainfall in an area compares to previous years' rainfall while using sampling data over a longer period. This makes the results more reliable and less divergent as would occur with a shorter period such as a 3- or 6-month SPI. ${ }^{13}$ The SPI was used to calculate the average rainfall in comparison to the previous 12 months over a 40 -year period. The SPI generally notes years from 0 to -1 as being low rainfall years, from -1 to -2 as being severe drought years and from -2 to -3 as an extreme drought. These graphs illustrate the decreasing precipitation tendencies in the Beaufort West area during the period 1993-2020. ${ }^{14}$

\section{Geographical and climatological features of Beaufort West}

Beaufort West, the primary focus of this study, was proclaimed a town in 1818 and was the first town in South Africa to receive municipal status as early as 1837 . The town is situated in the semi-arid central Great Karoo, $491 \mathrm{~km}$ from Cape Town and $961 \mathrm{~km}$ from Johannesburg. It is the major administrative, agricultural, and economic centre of the region. The town also serves as a major road and rail transit and is a crossing to many other South African towns. Beaufort West lies in a hollow between two hills and is flanked by the Gamka River in the west and the Kuils River in the east. Both rivers, which became semi-perennial as a result of urbanisation, flow in a generally north to south direction. With an average annual rainfall of a mere $250 \mathrm{~mm}$, the municipality has two main sources of water, namely groundwater and surface runoff, that is captured in two dams. The Springfontein Dam, an irrigation reservoir, was completed in 1869 but has run dry for several years because of diminishing precipitation. The Gamka Dam, completed in 1955, which provides $45 \%$ of the town's water supply, is the town's major freshwater reservoir but has been experiencing severe water-stressed conditions in recent years. Therefore, the town's water supply is heavily reliant on rainfall and under severe pressure.

Groundwater, extracted from boreholes, played an increasingly important role in the development of Beaufort West. Beaufort West is known for its so-called east-west trending 'dyke' cutting through the town. A dyke is a natural barrier to groundwater flow because of its low permeability. This barrier inhibits the southward migration of groundwater and effectively compartmentalises its flow. ${ }^{15,16,17,18,19}$

Throughout its municipal history, Beaufort West was plagued by occasional floods and recurring periods of prolonged drought. Visser ${ }^{20}$ and Vivier and Vivier ${ }^{15}$ determined that during the first 143 years of municipal record-keeping serious droughts occurred in 1823, 1827, 1856-1859, 1876-1878, 1898, 1915-1916, 1926, 1942-1949, 1951 and 1955-1966. In fact, Beaufort West's first water shedding appeared in January 1946, amidst the 1942-1949 drought, when the situation became so critical that water provision to inhabitants was cut on certain days and hours of the day. In October 1949, water rationing was imposed so that the daily water supply was restricted to $2 \mathrm{~h}$ only. ${ }^{21}$

As explained above, groundwater supplies would become crucial in periods when the town suffered from inevitable drought and water duress. Between 150 and 200 boreholes were drilled north of the dolerite dyke by the late 1940s in 
search of water and mainly in areas close to town. ${ }^{20}$ Since the 1970s, extensive geohydrological work was conducted by the Beaufort West Municipality and the Department of Water and Sanitation (DWS). Water is being extracted from four main municipal well fields all within a radius of $40 \mathrm{~km}$ from the town. The Brandwag well field is situated $40 \mathrm{~km}$ northeast of Beaufort West, Tweeling well field is situated about $30 \mathrm{~km}$ northeast of town and Lemoenfontein well field is $20 \mathrm{~km}$ north of town. The Town well field extends from the town to about $10 \mathrm{~km}$ north of Beaufort West. The Town well field supplies the majority of groundwater to the town, and the volume of water from this well field amounts to approximately $50 \%$ of the total groundwater supply. The ratio of groundwater to surface water usage is more or less $1: 1 .^{19}$

Over the years, more boreholes were drilled in the continued quest for more water sources. Eighteen boreholes were sunk since 1985 with an average depth of 49.83 m. Between 2007 and 2009, aquifer units south of the town's dolorite dyke were successfully explored, and several boreholes became available for use by the Beaufort West Municipality at the Hansrivier (southeast of town) and Droërivier (southwest of town) well fields, collectively known as the Southern well field. Thus over a 50-year period, starting in the 1970s, more than 300 boreholes had been drilled in the Beaufort West area, and some of these have become production boreholes for the town's water supply. ${ }^{16,19} \mathrm{Xu}$ et al. ${ }^{18}$ established that the importance of groundwater has increased from 50\% in 1978 to $55 \%$ in 2007.

A decisive moment in Beaufort West's water woes was the introduction of a water-borne sewerage system. Although such a sewerage scheme was considered as early as 1963 by the municipal council, the project eventually started in 1975 and was completed in 1978. The installation of flush toilets and running water to poor neighbourhoods has increased water demand, and the successful service provision had the unintended consequence of promoting further in-migration of inhabitants from under-served areas. ${ }^{6,16,22}$ Secondly, sustained urban growth between 1921 and the early 2000s had implications for municipal water demand in Beaufort West (Figure 1). This growth was also being accompanied by significant town expansion from 1945 to $2010 .{ }^{6}$ According to $\mathrm{Nel}$ et al., ${ }^{23}$ the growth of larger towns in the Karoo can be

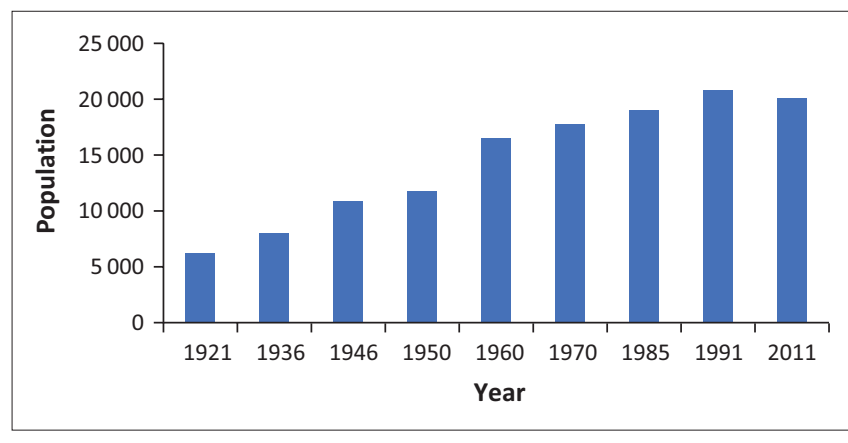

Source: Statistics South Africa. Beaufort West: Population Figures [data table online]. c2020 [cited 2021 May 2]. Available from: http://www.statssa.gov.za/?page_id=4286\&id=286

FIGURE 1: Population of Beaufort West from 1921 to 2011. attributed to their jobs, touristic and retirement appeal. Such towns are servicing an enlarged hinterland and a larger resident population while also providing services to an external market driven by tourism and leisure.

Field research by Holloway et al. ${ }^{6}$ suggested that heavy rain patterns had shifted spatially in recent years. According to information gathered from local monitors, rainfall changes had taken place since the 1980 s as rain began to fall predominantly over the town itself and not over the Gamka Dam mountain catchment as before. This had implications both for surface water supply, as well as access to groundwater, because of slower rates of aquifer recharge. These findings concur with the data in Figures 2 and 3.

In addition to the declining precipitation figures, Rose who conducted groundwater exploration for the Beaufort West Municipality between 2005 and $2008^{19}$ explains that the municipality's Brandwag well field measured continuous declining borehole yields. The declining water levels were mainly because of over-utilisation and subsequent dewatering. The Tweeling and Lemoenfontein well fields indicated similar declining trends. According to Mishra and Singh, ${ }^{13}$ the droughts that struck Beaufort West and its surrounding district in 2009-2011 and 2017-2019 can be described in four categories:

1. A meteorological drought that is defined as a lack of precipitation over a region for a period of time.

2. A hydrological drought that is related to a period with inadequate surface and subsurface water resources (lakes, reservoirs, rivers, streams and groundwater) for established water uses of a given water resources management system. It affects non-agricultural activities such as urban water consumption, ecosystem preservation, tourism and recreation.

3. An agricultural drought that refers to a period with declining soil moisture and consequent crop failure.

4. A socio-economic drought that is associated with the failure of water resources stems to meet water demands and thus associating droughts with a supply of and demand for water as enonomic good. Socio-economic drought occurs when the demand for an economic good exceeds supply as a result of a weather-related shortfall in the water supply.

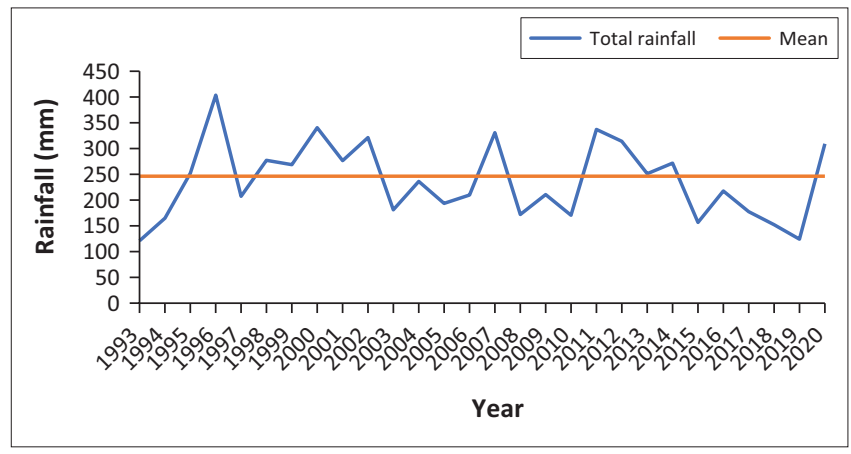

Source: South African Weather Service [serial online]. c2020 [cited 2020 Dec 10]. Available from: https://www.weathersa.co.za

FIGURE 2: Beaufort West total annual rainfall 1993-2020. 


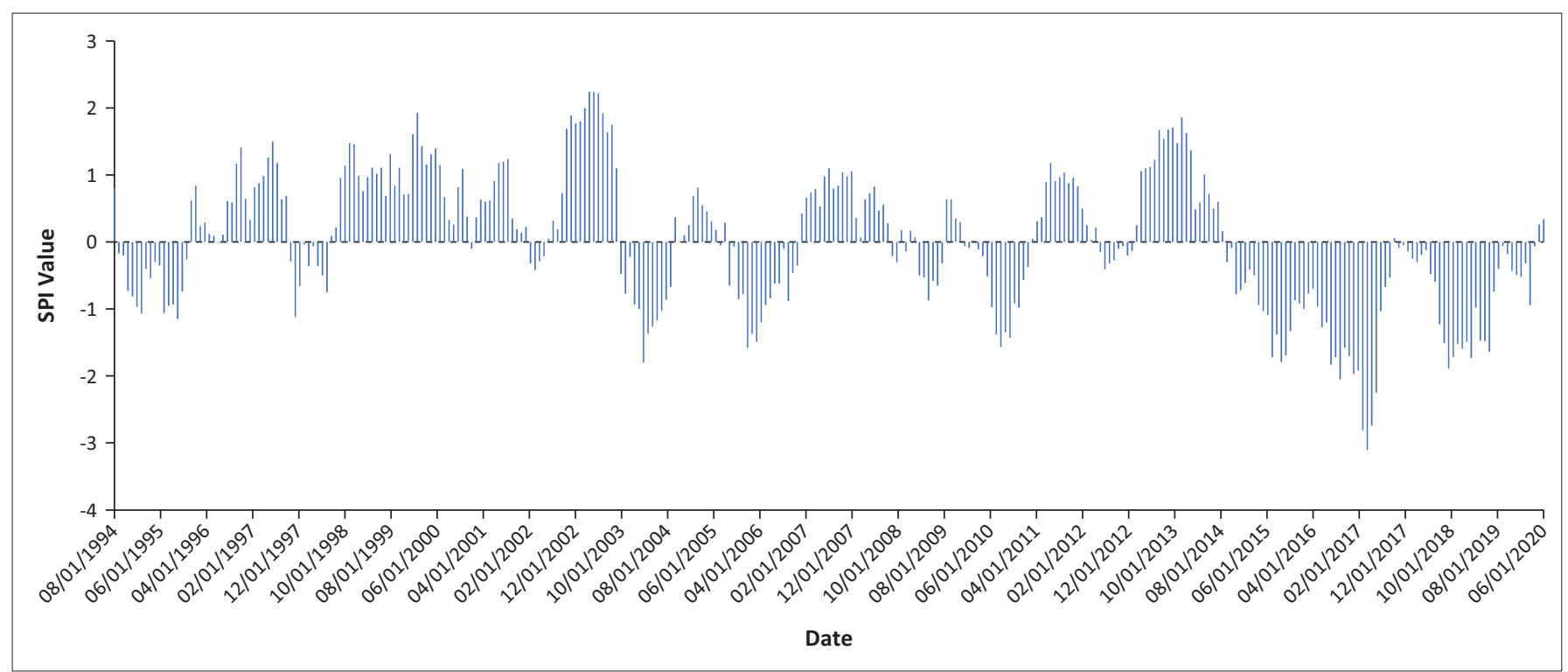

Source: South African Weather Service [serial online]. c2020 [cited 2020 Dec 10]. Available from: https://www.weathersa.co.za

FIGURE 3: Beaufort West SPI 12 months 1994-2020.

The combined effect of these manifestations of drought brought serious water famine to Beaufort West.

\section{The drought of 2009-2011}

Between 2009 and 2011, lower than normal rainfall was partly responsible for falling reservoir levels across the Central Karoo as the region experienced its worst drought since 1944. Although the municipality had introduced new water tariffs as early as July 2008 to discourage high water consumption, restrictions became necessary in 2009. These austerity measures were gradually increased as the water crisis deepened, and the Gamka Dam level dropped significantly. By May 2010, the water levels of the Gamka Dam, Beaufort West's major water resource, fell faster than expected, resulting in the reservoir emptying completely by September 2010 (Figure 4).

Consequently, 8500 households, representing approximately 36000 inhabitants, had to rely on 36 boreholes that provided $3700 \mathrm{~kL}$ water per day. From November 2008 to December 2010, groundwater levels within the town's important North End aquifer, normally recognised for its rapid recharge capacity, dropped from $13 \mathrm{~m}$ to $36 \mathrm{~m}$ below the ground level. As a result of the extremely hot and dry conditions, the water demand increased.

The dire water situation called for emergency measures. Drastic domestic water restrictions were imposed since January 2010, and a local disaster declaration was issued for Beaufort-West. Each household was restricted to $12 \mathrm{~kL}$ per month. At first, if consumers exceeded $15 \mathrm{~kL}$ per day consumption, a $200 \%$ surcharge was applied to their water accounts. In order to force down reduced water consumption, fines of R1000 were issued to perpetrators of water quotas. The water-stressed conditions prompted severe water load shedding from September to November 2010 when both ground and surface water supplies failed.

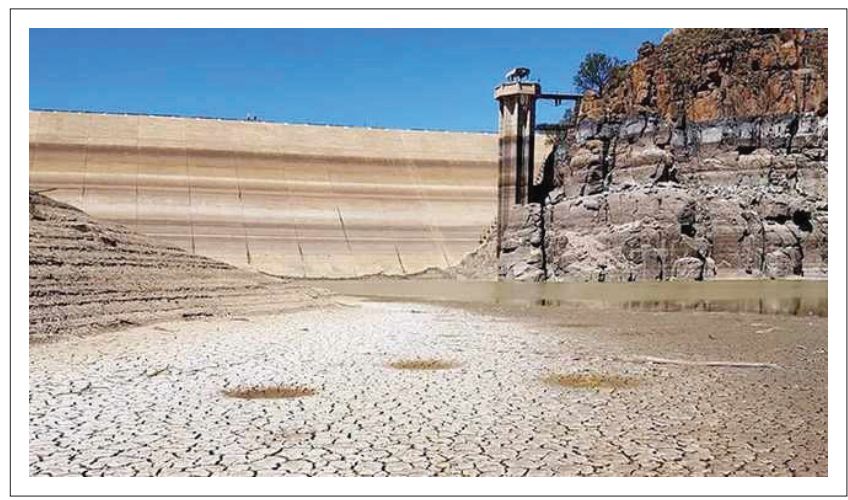

Source: Felix J. Water crisis: Beaufort West runs out of water. IOL Western Cape Government Photo [newspaper online]. 2017 Nov 13 [cited 2021 Jul 27]. Available from https://www.iol. co.za/news/south-africa/western-cape/watercrisis-beaufort-west-runs-out-ofwater-11979994 ${ }^{43}$

FIGURE 4: Gamka Dam with low water levels in 2017.

The town was divided into 12 wards staggered in 36-h water-shedding periods to allow for the recharge of the groundwater feeding the boreholes. Although the central business district, hospitals and industrial areas were not required to comply with water load shedding. Water was supplied through static and roaming tanks and even household-level distribution of $5 \mathrm{~L}$ bottled water every $48 \mathrm{~h}$. This constituted a major logistics exercise, and 90 temporary municipal staff members were locally employed for the operation. In addition, a country-wide public appeal was launched via radio and newspapers to donate potable bottled water to Beaufort West. ${ }^{6,24,25}$ By January 2011, visitors and private companies had dropped off $435000 \mathrm{~L}$ of bottled water. ${ }^{26}$

In January 2011, Beaufort West received relief funding amounting to R24 million from the National Treasury for South Africa's first reclamation plant. The project was completed within 6 months and was the country's first direct potable reuse plant. Treated wastewater effluent is conveyed directly to a water treatment facility for further treatment to 
drinking water standards. Sludge from pit latrines is boiled to kill pathogens and generate water vapour, which passes through several filters for further treatment. This treatment includes processes such as phosphate removal, predisinfection, ultrafiltration, reverse osmosis and advanced oxidation. The plant can process $12.3 \mathrm{~m}^{3}$ of sewage sludge and produce $10800 \mathrm{~L}$ of drinking water per day. The reclaimed water is pumped up to a service reservoir and blended with water from the Gamka Dam and the 36 boreholes in six aquifers in a ratio of 1:4. ${ }^{17,27,28}$

Nine months later, in June 2011, the Gamka Dam began to refill after substantial rainfall in its catchment associated with a low cut-off weather system. Water restrictions were consequently lifted. ${ }^{6}$

\section{The drought of 2017-2019}

Beaufort West enjoyed a reprieve of five years before the next severe drought struck again, with dire consequences for its inhabitants. According to King and Karoly, 292017 was set to be among the three hottest years on record, and by November 2018, Beaufort West experienced average-day temperatures between $35^{\circ} \mathrm{C}$ and $37^{\circ} \mathrm{C} .{ }^{30}$ By October 2017, the Gamka Dam was already dry. Five more boreholes were drilled in late 2017 when the municipality received R23 m in emergency government funding. As in 2009-2011, water restrictions and water load shedding were imposed although the industrial area was exempted from these measures for economic reasons. Water reduction devices such as low-pressure valves were also installed at schools to prevent water wastage. The reclamation plant, which had become the municipality's alternative water source since 2011 during water-stressed conditions, could normally provide $16 \%$ of the town's water needs. During the first half of 2018, it had been the last stable source of water but struggled to cope in the latter part of the year because less water became available to be cleaned and turned into potable water. The plant was designed to produce about 21.1 ML per day but at that rate could only produce 1 ML per day. On top of it all, the town's main sewage pipe broke in August 2018, which stopped waste going into the reclamation plant. This situation caused parts of the town to run out of water. By September 2018, a local disaster declaration was issued. . $^{30,31,32,33,34}$

Since October and November 2017, the Council for Geoscience (CGS) drilled five percussion boreholes to the east and south of Beaufort West as part of the Karoo Deep Drilling Project to investigate the geology and distribution and properties of shallow groundwater in the deep zone down to a depth of $169 \mathrm{~m}$. Two of these boreholes had the capacity to yield goodquality groundwater and were subsequently donated by the CGS to the Beaufort West Municipality. By 2018 and 2019, the municipality received a R23 m government financial grant, for example, to drill new boreholes and pipe water from the region south of the town. However, these boreholes proved inadequate to meet the pressing water needs. Additional water was supplied by passing tourists and non-governmental

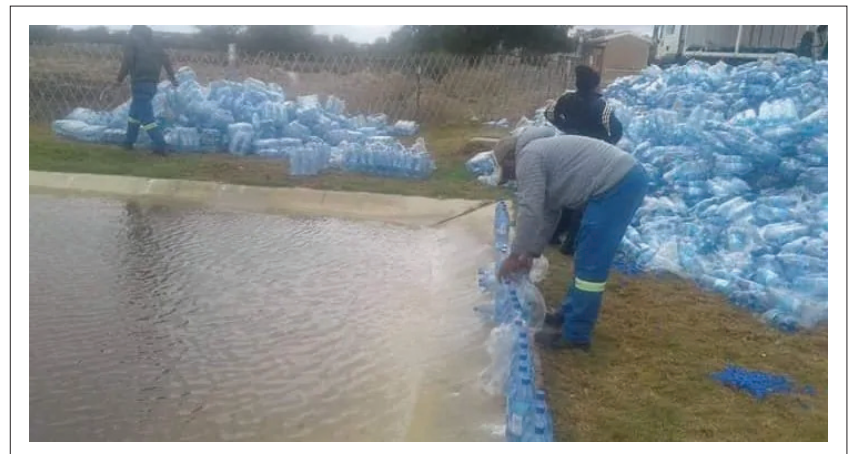

Source: Photograph taken by Andrew Sokolic, Beaufort West. Head T. Beaufort West drought: Residents begin filling up reservoirs with bottled water. The South African, Andrew Sokolic Facebook Photo [newspaper online]. 2017 Nov 13 [cited 2021 Jul 27]. Available from https:// www.thesouthafrican.com/news/beaufort-west-drought-water-dams $/{ }^{44}$

FIGURE 5: Municipal employees filling a retaining pond with bottled water.

charity organisations such as Gift of the Givers, Cape Town Water Warriors, as well as private businesses who trucked in water (Figure 5). Eventually, the municipality distributed stocks of emergency water when each household received two 5L containers of water per day..$^{30,32,35,36,37,38}$ By January 2019, the municipality's reserve water stock was critically low because of the forced distribution of emergency water. There were only $7002 \mathrm{~L}$ bottles of water, donated by Gift of the Givers, left in its emergency storage room. ${ }^{39}$

Fortunately, drought relief came for the inhabitants of Beaufort West when good rains returned in May 2019 and the Gamka Dam rapidly filled to $44 \%$ of its capacity. Water load shedding was rescinded, and water restrictions lowered to more tolerable levels. According to the municipality's new water distribution system, each household could utilise up to $15 \mathrm{~kL}$ water per month. ${ }^{40}$

\section{Discussion: Lessons learnt and applied}

There are many similarities between the Beaufort West droughts of 2009-2011 and 2017-2019 and how the municipal authority dealt with severe water-stressed situations. During both drought periods, austerity measures were imposed, such as water load shedding; local disaster declarations were issued; emergency distributions of bottled water took place and external public involvement were initiated through potable water donations to Beaufort West. Although the consequences of the 2017-2019 drought have not been investigated officially as yet, the findings of the report by Holloway et al. $^{6}$ on the Central Karoo drought of 2009-2011 is, in essence, applicable to both drought situations.

According to Mahed, ${ }^{41}$ unsustainable water extraction took place in Beaufort West. On average water levels in the aquifer dropped by $25 \mathrm{~m}$ over a period of 20 years because more water was pumped out than could be replaced by natural recharge. A long lingering problem that preceded the droughts was that the Beaufort West municipality faced difficulties in monitoring leaks and illegal abstractions because of outdated equipment such as water meters and 
infrastructure. Holloway et al. ${ }^{6}$ claim that there was widespread evidence of poor or non-existent water monitoring, with municipal water use remaining unaccounted for because of poor metering and leakages. Awareness of the town's acute water situation was, however, increased through other measures, including the publication of names of high water users in local newspapers. A number of drought risk drivers were also identified that served as warning signs for future drought situations. There was an increased water demand prior to the droughts that outpaced available supply, an under-recognition and investment in Integrated Water Resource Management (IWRM), including diversification of water supply options, and a limited capacity to understand and plan for concurrent drought and urban water scarcity risks. An important factor that delayed early signal detection of escalating water shortage risk was the inadequate understanding of what drought is and its interface with water scarcity. For example, IWRM anticipatory investment in new water infrastructure was severely limited as the Gamka Dam suffered unaccounted water losses of approximately 52\%. As the oldest municipality in South Africa, Beaufort West had an ageing and crumbling infrastructure that was prone to frequent water bursts. In addition, population growth and town expansion were not matched by investments to address identified needs for improved water supply development. In Beaufort West, a major risk driver was that the development of alternative water supplies had not kept pace with rising local demand.

In fact, the emergency demand for water involved a tension between sustainable water resource management and basic service provision. The provision of housing and basic services to previously disadvantaged communities was identified as a key measurable municipal performance area. Therefore, factors such as a steady growth in the provision of state housing, together with an expansion in both the number of new and the size of existing informal settlements within the municipal boundaries of Beaufort West, all contributed to the critical water-stressed conditions during the droughts of 2009-2011 and 2017-2019. Overall, annual and seasonal rainfall patterns that became increasingly unpredictable were identified as a major drought risk driver. The depletion of both groundwater and surface water from the Gamka Dam resulted in the municipality drawing on water supplies from the Springfontein irrigation dam located in the town, with negative consequences for local small farmers who faced reduced supplies. ${ }^{6}$

According to Meyer, ${ }^{26}$ tourists who had been staying over in Beaufort West's guest houses had put extra pressure on the already drained resources, which in itself put severe pressure on the water supply. But the town economy needed the tourists, therefore they were accommodated. In contrast, Holloway et al. $^{6}$ identified some adverse socio-economic impacts of the Beaufort West droughts as the severe water restrictions and water shedding impeded the normal flow of business. Bed and breakfast businesses outside of Beaufort West's town centre did suffer a loss of clientele and schools were also affected by the lack of water. A local car wash was forced to close while abattoirs suffered a downturn in production. Being a water-intense industry, it was forced to reduce the number of slaughtering days. The severe water restrictions and water shedding also impeded the normal flow of restaurants at petrol stations. In response, one of these enterprises installed two $10000 \mathrm{~L}$ water tanks to keep business running during scheduled water shedding. This ensured that toilets flushed, and dishes could be washed at such spots along the busy N1 autoroute between Cape Town and Johannesburg. In addition, a borehole was sunk, in anticipation that the meagre water supply to the central town might dry up. Sporting activities ceased because of a lack of available water to irrigate the school fields. In addition, an olive grove, originally planned to augment the income of one of the schools, died, because of a lack of irrigation water. Furthermore, the municipality reported the adverse effects of reduced grey water on the functioning of the sewerage system. Poor households noted that their gardens 'died' although many attempted to maintain these with grey water. The research done by Holloway et $a .^{6}{ }^{6}$ indicated that home gardens augmented livelihoods directly as a source of food or indirectly as an income source from vegetable sales. The loss of home gardening as a key drought amelioration strategy constituted an additional hardship for poorer households.

Matthews ${ }^{27}$ discusses the pros and cons of Beaufort West's reclamation plant that was installed as a result of the 20092011 drought. According to her, the advantages of water reclamation are that it conserves the available water supply, which reduces the need to abstract more water from surface or groundwater sources or build new dams, all of which have environmental and financial costs. It also reduces the volume of treated effluent discharged back into aquatic systems, where it may degrade natural water quality and cause the ripple effect of ecological changes associated with nutrient enrichment. In contrast, water reclamation for drinking purposes is considerably more expensive. Potable reuse plants employing reverse osmosis as a treatment method have high energy costs because the process relies on highpressure pumping to overcome osmotic pressure. The Beaufort West reclamation plant uses the reverse osmoses process as part of a multiple-barrier approach that also incorporates, as said, rapid sand filtration, ultrafiltration, UV-hydrogen peroxide and final chlorination. Reverse osmosis also increases costs because of highly concentrated brine, produced as a by-product, which is difficult to dispose of. Fortunately, the Beaufort West plant has some extra evaporation ponds available at the wastewater treatment works and the volumes are reasonably low.

\section{Conclusions}

In terms of its drought experiences in 2009-2011 and 20172019, Beaufort West faced the same problems that many of South Africa's other inland towns face in the new millennium..$^{32}$ Holloway et al. ${ }^{6}$ ascertained that the severity of these droughts in the Central Karoo was amplified by interacting risk drivers that had progressively escalated the 
risk of a widespread water shortage. These included greatly increased water consumption prior to the onset of meteorological drought conditions, both in agriculture and in a rapidly growing town population. Prior to the drought emergency, such conditions had been accompanied neither by rigorous water demand management nor systematic investment in water infrastructure and the requisite technical capacity to manage water supplies sustainably. Water resource development had not kept pace with demand. These risks were further exacerbated by a lack of systematic drought risk management planning.

It is quite clear that equilibrium should be reached between the water expectations of the community and the water availability in water-stressed towns such as Beaufort-West. Klopper ${ }^{42}$ observed that in many Karoo towns local authorities will have to face a growing hostility among inhabitants should water supply become frequently unavailable. With ageing infrastructure, prolonged droughts and increasing population growth, many of these towns do not enjoy a seamless, uninterrupted water supply anymore - a sure instigator of future social instability in such communities. In the light of global change, Beaufort West's acute water shortages during the droughts of 2009-2011 and 2017-2019 should serve as a timeous precursor to other rural towns in the arid regions of South Africa. It would entail comprehensive drought risk management planning and preventative strategies to empower such communities to deal effectively with future prolonged and devastating drought conditions.

Preventative strategies could include the following: Adequate population development plans should be introduced to rural communities that will keep track with finite rural water resources because future water scarcity will have a major impact on the social and economic development on these communities. Water-awareness programmes should be implemented in these towns to increase water-wise practices and an understanding of the scarcity and fragility of water sources, especially among under-educated town dwellers. The DWS should also identify and prioritise rural towns with capacity deficiencies in water management. Firstly, relevant municipal functionaries, as well as environmental officers and water workers, should be adequately trained in water planning strategies, water infrastructure maintenance and droughtmanagement. Secondly, a compulsory environmental focus should be introduced in school curricula to sensitise the youth about water conservation. Finally, innovate water preservation solutions should be pursued by the state. Depending on the outcomes of the ongoing geoscientific exploration in the Karoo Basin on the water-bearing qualities of aquifers, the artificial recharge of suitable aquifers should be considered. This could, for example, involve the injection of excess floodwaters into boreholes or transferring water into spreading basins where the subsurface is infiltrated.

\section{Acknowledgements}

The author would like to sincerely thank Mr Rouxan Rademan for collecting raw data rainfall and population figures.

\section{Competing interests}

The author certifies that he has no financial or personal relationships that may have inappropriately influenced him in writing this article.

\section{Author's contributions}

Wessel P. Visser is the sole author of this research article.

\section{Ethical considerations}

This article followed all ethical standards for research without direct contact with human or animal subjects.

\section{Funding information}

This research received no specific grant from any funding agency in the public, commercial or not-for-profit sectors.

\section{Data availability}

There are no restrictions on any data availability in this article. Data were collected from the Department of Water and Sanitation. Rainfall Data: Beaufort West. [serial online] c2020. [cited 2020 Dec 10]. Available from: https://www. dws.gov.za/Hydrology/Unverified/DetailRainfall.aspx?Sta tion=J2R004FW\&Type $=$ Flow \&Rain $=Y$ and from Statistics South Africa. Beaufort West: Population Figures. [serial online] c2020. [cited 2021 May 2]. Available from: http:// www.statssa.gov.za/?page_id $=4286 \& i d=286$

\section{Disclaimer}

The views and opinions expressed in this article are those of the author and do not necessarily reflect the official policy or position of any affiliated agency of the author.

\section{References}

1. Bodill TS. History of the Port Elizabeth water supply. Looking back, historical society of Port Elizabeth and Walmer. 1982;2:117.

2. Grant D. The politics of water supply: The history of Cape Town's water supply 1840-1920 [unpublished dissertation]. Cape Town: University of Cape Town; 1991.

3. Visser D, Jacobs A, Smit H. Water for Saldanha: War as an agent of change. Historia. 2008;53:130-161.

4. Musemwa M. Disciplining a dissident city: Hydropolitics in the city of Bulawayo, Matabeleland, Zimbabwe, 1980-1994. J South Afr Stud. 2006;32(2):239-254. https://doi.org/10.1080/03057070600656119

5. Le Maitre D, Colvin C, Maherry A. Water resources in the Klein Karoo: The challenge of sustainable development in a water-scarce area. SA J Sci. 2009;105(1-2):39-48. https://doi.org/10.1590/S0038-23532009000100019

6. Holloway A, Fortune G, Zweig P, et al. Eden \& Central Karoo Drought Disaster 2009-2011: The scramble for water [homepage on the Internet]. Stellenbosch University; 2012 [cited 2021 Apr 8]. Available from: http://www.riskreductionafrica. org/assets/files/EDEN\%20and\%20CENTRAL\%20KAROO\%20DROUGHT\%20 DISASTER\%202009.pdf

7. Meissner R, Jacobs-Mata I. South Africa's drought preparedness in the wate sector: Too little too late? [homepage on the Internet]. SA Institute of International Affairs Policy Briefing; 2016 [cited 2021 Jul 20], vol. 155, p. 1-4. Available from: https://saiia.org.za/research/south-africas-drought-preparedness-in-the-watersector-too-little-too-late/

8. Schreiner BG, Mungatana ED, Baleta H. Impacts of drought induced water shortages in South Africa: Economic analysis [homepage on the Internet] Water Research Commission Report No. 2604/1/18. 2018 [cited 2021 Jun 22] Available from: http://www.wrc.org.za/wp-content/uploads/mdocs/2604\%20 Vol\%201.pdf

9. Tfwala CM, Van Rensburg LD, Schall R, Dlamini P. Drought dynamics and interannual rainfall variability on the Ghaap Plateau, South Africa, 1918-2014. Phys Chem Earth Parts A/B/C. 2018;107:1-7. https://doi.org/10.1016/j.pce.2018.09.003 
10. Zhang $\mathrm{H}, \mathrm{Xu}$ Y, Kanyerere TA. Modelling approach to improving water security in a drought-prone area, West Coast, South Africa. Phys Chem Earth Parts A/B/C 2019;114:102797. https://doi.org/10.1016/j.pce.2019.08.005

11. Visser WP. A perfect storm: The ramifications of Cape Town's drought crisis J Transdisc Res South Afr. 2018;14(1):1-10. https://doi.org/10.4102/td.v14i1.567

12. Statistics South Africa. Beaufort West: Population figures [homepage on the Internet]. c2020. [cited 2021 May 2]. Available from: http://www.statssa.gov. za/?page_id $=4286 \&$ id $=286$

13. Mishra AK, Singh VP. A review of drought concepts. J Hydrol. 2010;391(1-2): 202-216. https://doi.org/10.1016/j.jhydrol.2010.07.012

14. South African Weather Service. c2020. [cited 2020 Dec 10]. Available from: https://www.weathersa.co.za

15. Vivier WGH, Vivier S. Hooyvlakte: Die Verhaal van Beaufort-Wes 1818-1968. Cape Town: Nasionale Boekhandel; 1970.

16. Erasmus GJ. Sub-streek: Die Sentrale Karoo: Gebied: Beaufort-Wes en Omgewing Navorsingsverslag. Stellenbosch: Stellenbosch University; 1986.

17. Marais P, Von Durckheim F. Beaufort West Water Reclamation Plant: Project. Water Sanit Afr. 2012;7:20-25. https://doi.org/10.10520/EJC106532

18. Xu Y, Mahed G, Van Wyk Y, et al. Towards a sampling and monitoring protocol of radioactive elements in fractured rock aquifers for groundwater re-source security in Beaufort West [homepage on the Internet]. Report to the Water Research Commission, Report No. 1694/1/12. 2012 [cited 2020 Nov 27]. Available from https://www.researchgate.net/publication/272495076

19. Rose RP. The characterisation of fractured Karoo Aquifers near Beaufor West [unpublished dissertation]. Pretoria: University of Pretoria; 2017 [cited 202 Jul 22]. Available from: https://repository.up.ac.za/bitsream/handle/2263/68254/ Rose_Characterisation_2018.pdf?sequence=1\&isAllowed=y

20. Visser WP. Between drought and deluge: A history of water provision to Beaufort West, ca. 1858-1955. New Contree [serial online]. 2020;85:1-21. Available from http://hdl.handle.net/10394/36923

21. Western Cape Archives and Records Service, Cape Town (hereafter WCARS) Archives of the Town Clerk Beaufort West (hereafter 3/BFW), Vol. 1/1/1/23,
Minutes of a Special Council Meeting, 1946: 401-402 and WCÁRS, 3/BFW, Vol. $1 / 1 / 1 / 23$, Minutes of a Special Council Meeting. 1949, p. 970-971.

22. WCARS, 3/BFW Box 263, Vol. 5/1/14, CA. Louw. Munisipaliteit Beaufort-Wes Rioolskema Vorderingsverslag. 1977.

23. Nel E, Taylor B, Hill T, Atkinson D. Demographic and economic changes in small towns in South Africa's Karoo: Looking from the inside out. Urban Forum. 2011;22:395. https://doi.org/10.1007/s12132-011-9131-z

24. Burger K. Gee jou water vir Beaufort. Rapport [newspaper online]. 2010 [cited 2021 Jun 20] Dec 12;5. Available from: https://www.news24.com/news24/ nuus24/suid-afrika/nuus/gee-jou-water-vir-beaufort-20101212

25. Steyn T. Beaufort-Wes het weer genoeg water. Die Burger [newspaper online] 2011 [cited 2021 Jun 20] Feb 16;6.

26. Meyer W. Water from sewage for Karoo town. Weekend Argus [newspaper

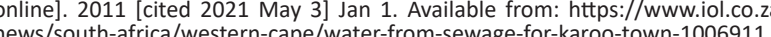

27. Matthews S. Water - Precious resource to be used again, and again and again... Water Wheel [serial online]. 2015 [cited 2021 July 24]; 14:26-29. Available from: http://www.wrc.org.za/wp-content/uploads/mdocs/WaterWheel 20153 May.pdf
28. Sorensen P. The chronic water shortage in Cape Town and survival strategies. Int J Env Stud. 2017:74:515-527. https://doi.org/10.1080/00207233.2017.13 35019

29. King A, Karoly D. 2017 is set to be among the three hottest years on record. The Conversation [serial online]. 2017 [cited 2021 May 17] Nov 6. Available from: https://theconversation.com/2017-is-set-to-be-among-the-three-hottest-yearson-record-86934

30. Lepule T. Beaufort West needs water after long drought. IOL [newspaper online] 2018 [cited 2021 Apr 14] Nov 4. Available from: https://www.iol.co.za/weekendargus/beaufort-west-needs-water-after-long-drought-17765948

31. Sonnekus S. Beaufort-Wes nog nie hééltemal droog. Die Burger 2017 Nov 14;10.

32. Kings S, Ritchie G. Beaufort West runs out of water. Mail \& Guardian [newspaper online]. 2018 [cited 2021 Apr 14] Aug 24. Available from: https://mg.co.za/ article/2018-08-24-00-beaufort-west-runs-out-of-water/

33. Kruger J. Beurtwater ingestel op Beaufort-Wes. Die Burger 2018 Sep 6;6

34. Nienaber M. Wes-Kaap help dié dorpe, hospitale, skole eerste met boorgate. Die Burger 2017 Nov 25;11.

35. Kruger J. Dag Zero kán voorkom word. Die Burger 2017 Dec 30;7.

36. Kruger J. Beurtwater maak nog verskil in dorp. Die Burger 2018 Sep 7;7.

37. Mosavel $\mathrm{H}$, Cole $\mathrm{D}$, Musetsha M. Investigations of deep hydrogeological targets in the Beaufort West Municipal Commonage. Geoclips [serial online]. 2018 [cited 2021 Oct 11];52:1. Available from: https://www.geoscience.org.za/images/ GeoClips/CGS2018-Geoclips-Vol52.pdf

38. Arnoldi M. Council for Geoscience starts deep drilling in Karoo basin. Mining Weekly [newspaper online]. 2020 [cited 2021 Oct 11] Sep 22;3. Available from: https://www.geoscience.org.za/images/council-for-geoscience-starts-deephttps://www.geoscience.org.za/ima
drilling-in-karoo-basin-2020-09-22

39. Somdyala K. Beaufort West about to run out of emergency bottled water Official. News24 [newspaper online]. 2019 [cited 2021 May 1] Jan 23. Available from: https://www.news24.com/SouthAfrica/News/beaufort-west-about-to-runout-of-emergency-bottled-water-official-20190123

40. Kruger J. Beurtwater in Beaufort-Wes opgehef en perke aangepas. Die Burger 2019 May $15 ; 1$.

41. Mahed G. Explainer: What there is to know about South Africa's aquifers. The Conversation [serial online]. 2018 Sep 5;1-3. [cited 2021 Jun 20]. Available from: https://theconversation.com/explainer-what-there-is-to-know-about-southafricas-aquifers-102660

42. Klopper $\mathrm{H}$. The organised expansion and permanent settlement of people in Boesmanland in correlation with accessible water sources, 1760-c.1960 [unpublished dissertation]. Stellenbosch: Stellenbosch University; 2020 [cited $2021 \mathrm{Jul}$ 25]. Available from: http://hdl.handle.net/10019.1/108154

43. Felix J. Water crisis: Beaufort West runs out of water. IOL Western Cape Government Photo [newspaper online]. 2017 Nov 13 [cited 2021 Jul 27] Available from: http://iol.co.za/news/south-africa/western-cape/watercrisesbeaufort-west-runs-out-of-water-11979994

44. Head T. Beaufort West drought: Residents begin filling up reservoirs with bottled water. The South African, Andrew Sokolic Facebook Photo [newspaper online] 2017 Nov 13 [cited 2021 Jul 27]. Available from https://www.thesouthafrican. $\mathrm{com} /$ news/beaufort-west-drought-water-dams/ 